American Journal of Agricultural and Biological Sciences 6 (3): 440-443, 2011

ISSN 1557-4989

(C) 2011 Science Publications

\title{
Influence of Debarking and Insecticidal Treatments Using Cypermethrin on Fresh Logs of Indonesian Pine, Pinus merkusii, on Attack by Ambrosia Beetle, Xyleborus sp.
}

\author{
Paimin Sukartana, Mohammad Muslich and Ginuk Sumarni \\ Centre for Forest Products Research and Development, \\ Biology and Wood Preservation Division, Jalan Gunung Batu 5, Bogor 16000, Indonesia
}

\begin{abstract}
Problem statement: Indonesian pine logs (Pinus merkusii Yungh. et de Vr.) are vulnerable to attack by ambrosia beetle Xyleborus sp. Fresh cut logs kept for months in logging area are subject to heavily attack by the beetles. Approach: An experiment was conducted to evaluate effectiveness of debarking and insecticidal treatments using cypermethrin on fresh logs of the wood species on attack by the ambrosia beetle. Insecticide solutions of 0.5, 1.0, 2.0, 2.5 and 3.0\% (v/v) were applied and the expeiment was kept in shady area for 60 days. Results: It was shown that debarking might increase the logs vulnerability. The beetle attacks on the untreated debarked logs (control) steadily increased from about 10 tunnels at the first week to about 80 tunnels per-square meter at the end of the experiment. Treatment with cypermethrin solution of $2.5 \%$ or more on debarked logs significantly protected the logs against the beetle. Meanwhile only a few tunnels were found on the bark-on logs at the first week and not more than 20 tunnels per-square meter at the end. Conclusion/Recommendation: The debarked fresh cut logs of the Indonesian pine should be treated with cypermethrin solution of $2.5 \%$ or more to prevent the ambrosia beetle attack Xyleborus sp. However bark-on logs are more preferred than the debarked ones because the bark will prevent the beetle attack and it is also environmentally more acceptable because no insectisidal treatment is required. Debarking process on the pine logs is also difficult so it will increase the production cost.
\end{abstract}

Key words: Density of tunnels, fresh logs, log protection, practical purposes

\section{INTRODUCTION}

An Indonesian pine tree (Pinus merkusii Yungh. et de Vr.) is one of the most important wood species planted by Perum Perhutani, a state owned forest enterprise, located mostly in Java, Indonesia. This species belongs to multipurpose species and therefore it is also recommended for industrial forest plantation (Hutan Tanaman Industri $=$ HTI). This pine tree is primarily designated for resin production. However, after resin production has not been economically visible anymore, the pine tree will be felled for wood production and planting rotation.

Precaution should be made in the pine logging because its fresh $\operatorname{logs}$ are vulnerable to attack by ambrosia beetle, Xyleborus sp. (Coleoptera: Scolytidae). Thousands of tunnels per-square meter of the beetle attack might occur on log surface if the logs are kept in forest for months. The beetles tunnel accross the wood grain into the logs reaching a depth of more than $15 \mathrm{~cm}$ (Sukartana, 1992). If infested logs are converted into lumber or veneer, damage caused by the beetle appears as numerous small black holes or tunnels, look as if has previously been punctured with wire that has been burnt (Hubbard, 1896). Those attacks reduce significantly if the logs are immediately extracted from the forest and then kept in an open area. If the logs are left in logging area for months, any treatment should be carried out to protect the logs against the beetle attack. These experiments were designated to evaluate effect of debarking and insecticidal treatments using cypermethrin on logs of this wood species to prevent the ambrosia beetle attack.

\section{MATERIALS AND METHODS}

Experiments were conducted in Buniayu, a forest district of Sukabumi, West Java, Indonesia. 60 fresh cut $\operatorname{logs}$ of Indonesian pine wood (Pinus merkusii) measuring of about $25 \mathrm{~cm}$ in diameter and $100 \mathrm{~cm}$ in

Correspoding Author: Paimin Sukartana, Centre for Forest Products Research and Development, Wood Entomologist, Biology and Wood Preservation Division, Jalan Gunung Batu No. 5, Bogor, Indonesia Tele: +62-251-8633378, Ext. 214, Fax: +62-251-8633413 
length were used for samples. The samples were divided into two groups, one was debarked and the other was left bark-on. Each group was then treated with insecticidal solution containing active ingredient of cypermethrin. There were six concentration levels (including control) of the insecticide that were employed, namely 0 (control), 0.5, 1.0, 2.0, 2.5 and $3.0 \%(\mathrm{v} / \mathrm{v})$ from the commercial formula.

Five replicates were prepared. Each log surface was sprayed evenly with the insecticide solution at amount of $50 \mathrm{~mL}$. After spraying, the logs were randomly assigned and then put on several pairs of bamboo rail that had been prepared in a shady area. Six test logs, representing each treatment concentration, were randomly put on a pair of the bamboo rails, with a gap between the logs was one meter to minimize interference among the treatments (Fig. 1). The experiments were arranged according to the Randomized Complete Block Design (RCBD) (Steel and Torrie, 1980).

The experiments were daily inspected for two months to record number of beetle tunnels on each test log. Beetle attack density was determined according to the number of tunnels per-square meter of log surface. The entire data were transformed into $\sqrt{ }(Y+1 / 2)$ for ANOVA analysis and then Dunnett's analyses were also conducted for cumulative data at every tree-four day inspection to determine difference of beetle infestation intensity between the treated and untreated logs. A regression analysis was also conducted to evaluate effect of debarking on vulnerability of the $\log$ s to the beetle attack from time to time at those observation intervals.
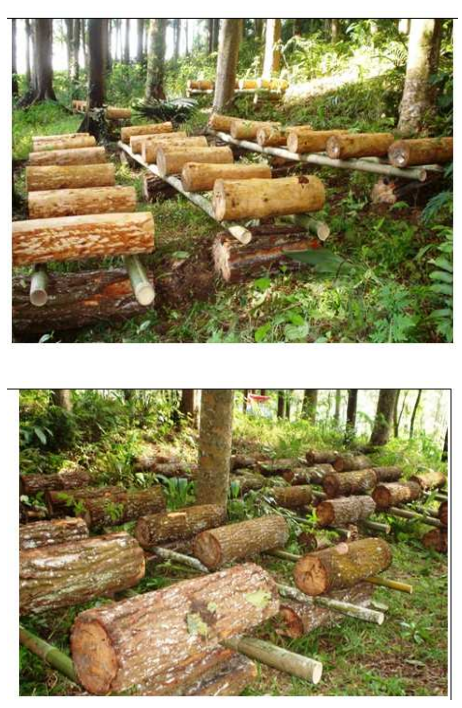

Fig. 1: Experiment installment. Above: the barked logs, Below: the bark-on logs

\section{RESULTS AND DISCUSSION}

Debarking effect: It was shown that debarking on the pine logs significantly increased the logs vulnerability against the beetle infestations (Fig. 2). Regression equations $\mathrm{Y}=10.16+1.38 \mathrm{X}, \mathrm{r}^{2}=0.97$ and $\mathrm{Y}=-2.82$ $+0.32 \mathrm{X}, \mathrm{r}^{2}=0.92$, where $\mathrm{Y}=$ number of tunnels and $\mathrm{X}=$ day of observation, for the debarked and bark-on treatment respectively, quantitatively confirmed the increasing density of tunnels of the beetle attack on the logs from day to day. This Figure also showed that until about day 20, the bark-on $\operatorname{logs}$ were still relatively sound, only less then 5 tunnels $/ \mathrm{m}^{2}$ were found. Conversely, density of beetle attacks on the debarked log was much higher, since the first week of the experiment installment.

This result was similar to those of previous experiments on ramin wood attacked by ambrosia beetle Platypus Trepanatus. (Sukartana, 1989), on the pine by Xyleborus sp. (Sukartana, 1994) and that on various tropical pine species in Brazil (Flechtmann et al., 1999). Kishi et al. (1973) Have also mentioned that debarked logs of Shorea spp. are more attractive to ambrosia beetles and other wood borers.

Amount of log volatiles plays an important role in the beetle attraction. Debarking logs will expose all sapwood. This causes greater surface area from which much more amount of host (chemical) volatiles can be released and therefore more beetle attacks occur (Flechtmann et al., 1999).

Among these volatiles, ethanol resulted from anaerobic respiration (Graham, 1968 and Moeck, 1970) and $\alpha$-pinene which is released from phloem of the debarked logs is known to attract the beetle infestation (Shore and Lindgren, 1996; Miller and Rabaglia, 2009).

The amount of volatiles released from the bark-on logs was probably much lower than that from the debarked one because the volatiles from phloem were sealed off by the bark. Therefore, it was reasonable if the bark-on logs were less attractive to the ambrosia beetles than the debarked ones. However, this does not mean that bark-on logs always safe from the ambrosia beetle attack.

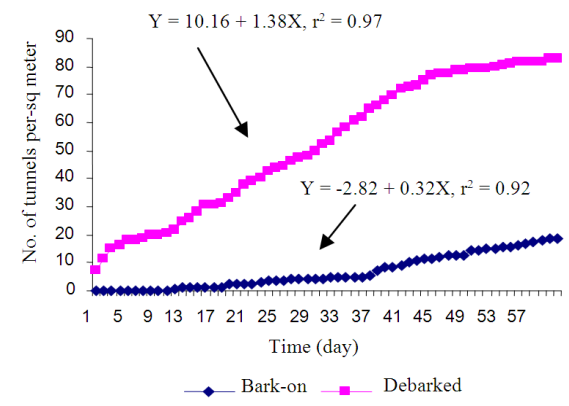

Fig. 2: Density of the beetle tunnels from day to day on the debarked and bark-on pine logs 
Am. J. Agri. \& Biol. Sci., 6 (3): 440-443, 2011

Table 1: Mean tunnel density of ambrosia beetle attack at each observation period on debarked Indonesian pine $\operatorname{logs}^{1}$

\begin{tabular}{|c|c|c|c|c|c|c|c|c|}
\hline \multirow[b]{2}{*}{ Treatment (\%) } & \multicolumn{7}{|c|}{ Number of tunnels per $\mathrm{m}^{2}$ at day } & \multirow[b]{2}{*}{28} \\
\hline & 1 & 4 & 8 & 12 & 16 & 20 & 24 & \\
\hline$\overline{0 \text { (Control) }}$ & $7.07 \mathrm{a}$ & $16.20 \mathrm{a}$ & $19.76 \mathrm{a}$ & $24.63 \mathrm{a}$ & $30.53 a$ & $37.61 \mathrm{a}$ & $43.57 \mathrm{a}$ & $48.22 \mathrm{a}$ \\
\hline 0.5 & $3.09 \mathrm{~b}$ & $5.24 \mathrm{~b}$ & $7.71 \mathrm{a}$ & $13.64 \mathrm{a}$ & $17.80 \mathrm{a}$ & $23.17 \mathrm{a}$ & $30.64 a$ & $32.02 \mathrm{a}$ \\
\hline 1.0 & $1.58 \mathrm{~b}$ & $3.34 \mathrm{~b}$ & $5.36 \mathrm{~b}$ & $6.99 \mathrm{~b}$ & $8.21 \mathrm{~b}$ & $11.29 \mathrm{~b}$ & $13.65 \mathrm{~b}$ & $14.90 \mathrm{~b}$ \\
\hline 2.0 & $0.85 \mathrm{~b}$ & $3.80 \mathrm{~b}$ & $4.95 \mathrm{~b}$ & $6.56 \mathrm{~b}$ & $7.94 \mathrm{~b}$ & $9.30 \mathrm{~b}$ & $10.91 \mathrm{~b}$ & $12.97 \mathrm{~b}$ \\
\hline 2.5 & $0 \mathrm{~b}$ & $0.91 b$ & $1.60 \mathrm{~b}$ & $1.60 \mathrm{~b}$ & $2.96 \mathrm{~b}$ & $3.63 b$ & $4.56 \mathrm{~b}$ & $5.49 \mathrm{~b}$ \\
\hline 3.0 & $0 \mathrm{~b}$ & $0.90 \mathrm{~b}$ & $1.57 \mathrm{~b}$ & $2.23 \mathrm{~b}$ & $2.46 \mathrm{~b}$ & $3.40 \mathrm{~b}$ & $5.60 \mathrm{~b}$ & $5.53 b$ \\
\hline
\end{tabular}

Table 1: Continues

\begin{tabular}{|c|c|c|c|c|c|c|c|c|}
\hline \multirow[b]{2}{*}{ Treatment (\%) } & \multicolumn{7}{|c|}{ Number of tunnels per $\mathrm{m}^{2}$ at day } & \multirow[b]{2}{*}{60} \\
\hline & 32 & 36 & 40 & 44 & 48 & 52 & 56 & \\
\hline 0 (Control) & $56.23 \mathrm{a}$ & $64.69 a$ & $71.94 \mathrm{a}$ & $76.98 \mathrm{a}$ & $78.75 a$ & $79.85 a$ & $81.41 \mathrm{a}$ & $82.95 a$ \\
\hline 0.5 & $37.53 \mathrm{a}$ & $42.68 \mathrm{a}$ & $47.25 \mathrm{a}$ & $49.90 \mathrm{a}$ & $51.23 \mathrm{a}$ & $52.10 \mathrm{a}$ & $52.32 \mathrm{a}$ & $53.18 \mathrm{a}$ \\
\hline 1.0 & $16.02 b$ & $19.31 b$ & $22.17 b$ & $23.85 b$ & $26.01 \mathrm{~b}$ & $28.44 b$ & $31.11 \mathrm{~b}$ & $32.56 b$ \\
\hline 2.0 & $13.63 b$ & $14.51 \mathrm{~b}$ & $15.62 b$ & $16.97 \mathrm{~b}$ & $17.62 b$ & $18.73 b$ & $18.97 \mathrm{~b}$ & $19.43 b$ \\
\hline 2.5 & $6.17 b$ & $7.35 b$ & $8.28 b$ & $10.09 \mathrm{~b}$ & $11.01 \mathrm{~b}$ & $12.41 b$ & $13.11 \mathrm{~b}$ & $13.58 \mathrm{~b}$ \\
\hline 3.0 & $6.87 \mathrm{~b}$ & $7.76 \mathrm{~b}$ & $9.30 \mathrm{~b}$ & $9.53 b$ & $10.41 b$ & $10.63 b$ & $12.18 \mathrm{~b}$ & $13.08 \mathrm{~b}$ \\
\hline
\end{tabular}

${ }^{1}$ : Means followed by the same letter within each column not significantly different according to Dunnett's test, $\mathrm{p}<0.05$

Table 2: Means tunnel density of ambrosia beetle attack at each observation period on bark-on Indonesian pine $\operatorname{logs}{ }^{1}$ Number of tunnels per $\mathrm{m}^{2}$ at day

\begin{tabular}{|c|c|c|c|c|c|c|c|c|}
\hline Treatment $(\%)$ & 1 & 4 & 8 & 12 & 16 & 20 & 24 & 28 \\
\hline 0 (Control) & $0.16 \mathrm{a}$ & $0.161 \mathrm{a}$ & $0.16 a$ & $1.27 \mathrm{a}$ & $1.48 \mathrm{a}$ & $2.19 \mathrm{a}$ & $3.40 \mathrm{a}$ & $4.05 \mathrm{a}$ \\
\hline 0.5 & $0.45 \mathrm{a}$ & $0.45 \mathrm{a}$ & $0.45 \mathrm{a}$ & $0.68 \mathrm{a}$ & $1.10 \mathrm{a}$ & $1.77 \mathrm{a}$ & $1.99 \mathrm{a}$ & $1.99 \mathrm{a}$ \\
\hline 1.0 & $0 \mathrm{a}$ & $0 \mathrm{a}$ & $0 \mathrm{a}$ & $0.22 \mathrm{a}$ & $0.22 \mathrm{a}$ & $0.43 \mathrm{a}$ & $0.43 \mathrm{a}$ & $1.07 \mathrm{a}$ \\
\hline 2.0 & $0.49 \mathrm{a}$ & $0.49 \mathrm{a}$ & $0.49 \mathrm{a}$ & $0.73 a$ & $0.73 a$ & $1.18 \mathrm{a}$ & $1.44 \mathrm{a}$ & $2.13 \mathrm{a}$ \\
\hline 2.5 & $0.23 \mathrm{a}$ & $0.23 \mathrm{a}$ & $0.23 a$ & $1.20 \mathrm{a}$ & $1.69 \mathrm{a}$ & $2.44 \mathrm{a}$ & $3.18 \mathrm{a}$ & $5.68 \mathrm{a}$ \\
\hline 3.0 & $0 \mathrm{a}$ & $0 \mathrm{a}$ & $0 \mathrm{a}$ & $0 \mathrm{a}$ & $0.24 \mathrm{a}$ & $0.24 \mathrm{a}$ & $0.24 \mathrm{a}$ & $1.15 \mathrm{a}$ \\
\hline
\end{tabular}

Table 2: Continues

\begin{tabular}{|c|c|c|c|c|c|c|c|c|}
\hline \multirow[b]{2}{*}{ Treatment } & \multicolumn{7}{|c|}{ Number of tunnels per $\mathrm{m}^{2}$ at day } & \multirow[b]{2}{*}{60} \\
\hline & 32 & 36 & 40 & 44 & 48 & 52 & 56 & \\
\hline$\overline{0 \text { (Control) }}$ & $4.73 \mathrm{a}$ & $5.44 a$ & $9.08 \mathrm{a}$ & $11.53 \mathrm{a}$ & $12.46 \mathrm{a}$ & $15.00 \mathrm{a}$ & $16.98 \mathrm{a}$ & $18.56 \mathrm{a}$ \\
\hline $0.5 \mathrm{~mL} \mathrm{~L}^{1}$ & $2.43 \mathrm{a}$ & $3.09 \mathrm{a}$ & $5.88 \mathrm{a}$ & $8.46 \mathrm{a}$ & $9.35 \mathrm{a}$ & $11.20 \mathrm{a}$ & $13.13 \mathrm{a}$ & $15.27 \mathrm{a}$ \\
\hline $1.0 \mathrm{~mL} \mathrm{~L}^{1}$ & $1.07 \mathrm{a}$ & $1.51 \mathrm{a}$ & $2.98 \mathrm{a}$ & $5.55 \mathrm{a}$ & $6.19 a$ & $7.91 \mathrm{a}$ & $9.62 \mathrm{a}$ & $10.93 \mathrm{a}$ \\
\hline $2.0 \mathrm{~mL} \mathrm{~L}^{1}$ & $3.96 \mathrm{a}$ & $4.21 \mathrm{a}$ & $6.94 \mathrm{a}$ & $8.84 \mathrm{a}$ & $10.05 \mathrm{a}$ & $11.64 \mathrm{a}$ & $12.81 \mathrm{a}$ & $14.42 \mathrm{a}$ \\
\hline $2.5 \mathrm{~mL} \mathrm{~L}^{1}$ & $6.88 \mathrm{a}$ & $8.53 \mathrm{a}$ & $9.27 \mathrm{a}$ & $10.27 \mathrm{a}$ & $10.76 a$ & $12.92 \mathrm{a}$ & $13.82 \mathrm{a}$ & $14.67 \mathrm{a}$ \\
\hline $3.0 \mathrm{~mL} \mathrm{~L}^{1}$ & $2.31 \mathrm{a}$ & $2.31 \mathrm{a}$ & $3.00 \mathrm{a}$ & $4.88 \mathrm{a}$ & $4.84 \mathrm{a}$ & $9.41 \mathrm{a}$ & $13.16 \mathrm{a}$ & $16.82 \mathrm{a}$ \\
\hline
\end{tabular}

Debarking for ramin (Gonystylus bancanus) logs is compulsory to reduce the ambrosia beetle attacks. Ramin logs that have been debarked will dry faster so they will not be suitable for infestation by the beetles.

Insecticidal treatment: Table 1 showed that insecticidal treatment reduced the ambrosia beetle attack on the debarked logs. ANOVA analyses resulted that calculated $F$ values, ranging from 7.4726.46, were much higher than that of tabular $F$ value that is only 2.62 (DF 5/24, p<0.05). Dunnett's analyses showed that treatment with the insecticidal solution of $0.5 \%$ was significantly different only from control until four days, whereas the others were until 60 days, at the end of the experiment.
For practical purposes, where effectiveness of a treatment is determined by number of beetle attacks of not more than 5 tunnels per-square meter (Martawajaya and Abdurrohim, 1978) the chemical solutions of 0.5, 1.0, 2.0, 2.5 and $3.0 \%$ were respectively effective for 1 , 4, 8, 24 and 20 days after treatment. Effectiveness of the treatment using solutions of 2.5 and $3.0 \%$ should be considered between 20 and 24 days because number of tunnels each of 4.56 and 5.60 per $\mathrm{m}^{2}$ respectively at day 24 was rather confusing. Therefore, the chemical solutions of 2.5 and $3.0 \%$ should be preferred because these solutions were able to protect the logs for about three weeks or even more. This implied that the debarked 
logs that have been treated should not be left in the forest for not more than 3-4 weeks after the treatments.

It seemed insecticidal treatment on the bark-on logs did not give any significant effect on the beetle attacks (Table 2). ANOVA analyses of data showed that all calculated $F$ values (ranging from 0.21-2.12) were lower than tabular F value $(\mathrm{DF}, 5 / 24=2.62$, p<0.05). This means that there was insignificantly different between control and the insecticidal treatment. This was much better than the barked log treated with the insecticide solution, eventhough with the highest concentration, $3.0 \%$. This means that the bark itself was properly able to protect the logs against the ambrosia beetle attacks.

\section{CONCLUSION}

Debarking Indonesian pine logs should be treated with insecticide because the logs became more susceptible to attack by the ambrosia beetle than the bark-on ones. Treatment with insecticidal solution containing active ingredient of cypermethrin $2.5 \%$ or more was effective for protecting the debarked log against the beetle attacks for about three weeks or more.

The bark-on pine logs were more resistant to the beetle attacks. Without insecticidal treatment, these logs will not be significantly infested by the beetle for about one month after felling. This was much longer than the treated debarked logs. These data lead to recommend that debarking on the pine logs and then employing insecticide for protecting the logs against the ambrosia beetle attacks is not necessary. Therefore, debarking practice on pine logs is very difficult and insecticidal treatment is environmentally unacceptable.

\section{ACKNOWLEDGEMENTS}

We thank our technicians, Mr. Sumardi and Mr. Didik Achmad Sudika, for their dedicated helps during the trial.

\section{REFERENCES}

Flechtmann, C.A.H., A.L.T. Ottati and C.W. Berisford, 1999. Attraction of ambrosia beetles (Coleoptera: Scolytidae) to different tropical pine species in Brazil. Environ. Entomol., 28: 649-658.

Graham, K. 1968. Anaerobic induction of primary chemical attractancy for ambrosia beetles. Can. J. Zool. 46: 905-908. DOI:10.1139/z68-127

Miller, D.R. and R.J. Rabaglia, 2009. Ethanol and (-)$\alpha$-pinene: Attractant kairomones for bark and ambrosia beetles in the Southeastern US. J. Chem. Ecol., 35: 435-448. DOI:10.1007/s10886-0099613-9 PMID: 19294470

Kishi, Y., N. Ido, and T. Murakami, 1973. Attack to Shorea spp.(Dipterocarpacae) by ambrosia beetles and wood borers and its preventive treatment by insecticides. J. Jpn. For. Soc., 55: 301-306.

Martawajaya, A. and S. Abdurrohim, 1978. Protection of ramin logs against abrosia beetle attack. Report No. 117. Fores Products Research Institute, Bogor, Indonesia.

Moeck, H.A. 1970. Ethanol as the primary attractant for the ambrosia beetle Trypodendron lineatum (Coleoptera: Scolytidae). Can. Entomol. 102: 985995. DOI: 10.4039/Ent102985-8

Shore, T.L. and B.S. Lindgren, 1996. Effect of ethanol and $\alpha$-pinene on response of ambrosia beetle,Trypodendron lineatum, to lineatin-baited funnel and drainpipe traps. J. Chem. Ecol., 22: 2187-2196. DOI:10.1007/BF02029539

Steel, R.G.D. and J.H. Torrie, 1980. Principles and Procedures of Statistics: A Biometrical Approach. 2nd Edn., McGraw-Hill, Auckland, ISBN: 0070665818, pp: 633. 